\title{
Determination of Stiffness of Triple Spring Built in a Bogie of a Rail Vehicle
}

Mária Maňurová, Andrej Suchánek

Faculty of Mechanical Engineering, Department of Transport and Handling Machines. University of Zilina. Univerzitná 8215/1, 01026 Žilina. Slovak Republic. E-mail: maria.manurova@fstroj.uniza.sk, andrej.suchanek@fstroj.uniza.sk

The article deals with the calculation of stiffness of a secondary suspension spring built in a bogie of a rail vehicle with a tilting car body. The vertical stiffness of the springs was calculated using the ANSYS program. The results were compared with calculated values afterwards. The lateral stiffness was evaluated in a similar manner. Analytical method by Gross, Wahl, Budrick, Timoshenko and Ponomarev was used for comparison with numerical values. The ANSYS simulation was performed for calculating the vertical stiffness of the triple springs. The most suitable analytical method is a method by Timoshenko and Ponomarev, where the percentage difference was the smallest. The obtained data will be used as an input for the design of coil springs which will be implemented in a model of a vehicle with a tilting car body, for which the comfort values during transition in curve will eventually be determined.

Keywords: Secondary Suspension, Spring, Bogie, Stiffness

\section{Acknowledgement}

The work was supported by the Scientific Grant Agency of the Ministry of Education of the Slovak Republic and the Slovak Academy of Sciences in project No. 1/0347/12: "Railway wheel tread profile wear research under the rail vehicle in operation conditions simulation on the test bench", project No. 1/0383/12: "The rail vehicle running properties research with the help of a computer simulation." and the project No. APVV-0842-11: "Equivalent railway operation load simulator on the roller rig".

Research-Educational Center of Rail Vehicles (VVCKV).

\section{References}

[1] SIMPACK Documentation. (2015) 2001. 4168 p.

[2] CHUDZIKIEWICZ, A., BOGACZ, R., OSTERMEYER, G-P. (2014). Selected Dynamical Problems in Mechanical Systems, Theory and Applications in Transport. Oficyna Wydawnicza Politechniki Warszawskiej, 2014. ISBN 978-83-7814-282-9.

[3] LACK, T., GERLICI, J. Dynamics analysis of oscilation systems with lumped masses. (In Slovak) Current problems in rail vehicles: PRORAIL. XIII. International conference. Pardubice: University of Pardubice. ISBN 807194-105-0.

[4] LACK, T., GERLICI, J. Rail geometry analysis (from the point of view of wearing in the operation). (In Slovak). Communications - scientific letters of the University of Žilina. ISSN 1335-4205.

[5] LACK, T. (2013). Wheel/rail contact interaction phenomena for vehicles in track dynamics evaluation. In: Advanced methods in computational and experimental mechanics. London: Pearson Education Limited, 2013. S. 113140. ISBN 978-1-78434-069-8.

[6] LACK, T., GERLICI, J. (2014) A modified strip method to speed up the tangential stress between wheel and rail calculation. In: Applied mechanics and materials. Vol. 486 (2014) S. 371-378. ISSN 1660-9336.

[7] GERLICI, J., LACK, T. Structural analysis of various vehicle constructions. In: Numerical Methods in Continuum Mechanics. Models, Numerical Methods and Applications". S. 360-365.

[8] LACK, T., GERLICI J. (2013). The FASTSIM method modification in speed up the calculation of tangential contact stresses between wheel and rail. In: Manufacturing technology: journal for science, research and production. ISSN 1213-2489. Vol. 13, no. 4, pp. 486-492.

[9] GERLICI, J., LACK, T., HARUŠINEC, J. (2013). The test stand load modulus implementation for the realistic railway operation in the laboratory conditions. In: Manufacturing technology: journal for science, research and production. Vol. 13, no. 4 (2013) Pp. 444-449. ISSN 1213-2489.

[10] GERLICI, J., LACK, T. (2005). Contact railway wheelset and track. (In Slovak) University of Žilina. ISBN 808070-317-5.

[11] GERLICI, J., LACK, T. (2003). Railway wheel and rail geometry geometry influence on ride properties of the vehicle. (In Slovak) In: Current problems in rail vehicles - Prorail 2003. XVI. International conference. Žilina 8.10. October 2003, Slovensko. Žilina: VTS pri ŽU. 2003. S. 163-171. ISBN 80-968823-6-8. 
[12] GERLICI, J., LACK, T. (2005). Transport means properties analysis. (In Slovak) University of Žilina, 2005. ISBN 80-8070-408-2.

[13]IZER, J., JANDA, J., MARUNA, Z., ZDRU゚BEK, S. (1985). Rail vehicle. (In Czech) ALFA Bratislava. 1985.

[14]VÁGNER, J. - HÁBA, A. (2010). Options determination of lateral stiffness flexi-coil springs. In: VTS ČD no. 30/2010. URL: http://vtsb.cd.cz/VTS/CLANKY/vts30/3008.pdf.

[15]DIŽO, J., BLATNICKÝ, M. (2015). Multibody system dynamics as a tool of the vehicle behaviour diagnostics (In Slovak) TSD : XII international technical systems degradation conference : Liptovský Mikuláš, 8. - 11. April 2015. Warszawa: Polskie Naukowo-Techniczne Towarzystwo Exploatacyjne, 2015. S. 164-167. ISBN 978-83930944-7-9

[16]DIŽO, J. GERLICI, J., LACK, T. (2011). State of the art tools for railway vehicles systems dynamical analysis performance. In: TRANSCOM 2011: 9th European conference of young research and scientific workers: Žilina, June 27-29, 2011, Slovak Republic. Žilina: University of Žilina, 2011. Pp. 35-38. ISBN 978-80-554-0375-5.

[17]ŠŤASTNIAK, P. (2015) Design of non-standard long railway wagon with variable use of loading platform. In: TRANSCOM 2015: 11-th European conference of young researchers and scientists : Žilina, June 22-24, 2015, Slovak Republic. Žilina: University of Žilina, 2015. S. 242-247. ISBN 978-80-554-1048-7.

[18]ŠŤASTNIAK P., MORAVČÍK, M. (2015). Control mechanism modification of mobile cross-beam in freight wagon. In: Technológ. ISSN 1337-8996. Vol. 2 (2015), s. 217-221.

[19]SMETANKA, L., GERLICI, J., PELAGIĆ, Z. (2014). Homogenization of fibers reinforced composite materials for simulation analysis. (In Slovak) In: Dynamics of rigid and deformable bodies 2014. XII. International scientific conference Ústí nad Labem, Czech Republic, 8.-10. October 2014. FVTM UJEP, 2014. ISBN 978-80-7414-7494.

[20]SKOČILASOVÁ, B., SKOČILAS, J., SOUKUP, J. (2008). Experimental determination of natural frequencies and stiffness of suspension of flexible mounted body, application on road and railway vehicles (In Czech). Acta Mechanica Slovaca, No. 3-B/2008, CD ROM, vol. 12, Košice, 2008. ISSN 1335-2393, pp. 715 - 726.

[21]POLACH, P.: (2015). Influene of the Shock Absorbers Type Change at Stress of the Trolleybus Chassis. In: Manufacturing technology. Vol. 15, No. 1, 2015. Pp. 77 - 86. ISSN 1213-2489 